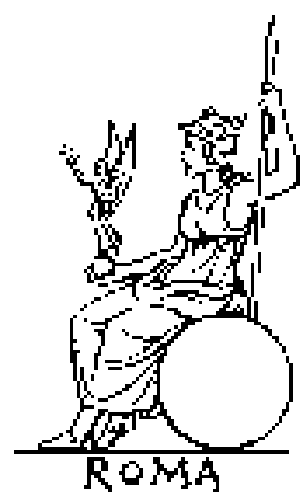

Funeral Lights in Roman Sepulchral Monuments

Author(s): G. McN. Rushforth

Source: The Journal of Roman Studies, Vol. 5 (1915), pp. 149-164

Published by: Society for the Promotion of Roman Studies

Stable URL: http://www.jstor.org/stable/296303

Accessed: 09/05/2014 13:53

Your use of the JSTOR archive indicates your acceptance of the Terms \& Conditions of Use, available at http://www.jstor.org/page/info/about/policies/terms.jsp

JSTOR is a not-for-profit service that helps scholars, researchers, and students discover, use, and build upon a wide range of content in a trusted digital archive. We use information technology and tools to increase productivity and facilitate new forms of scholarship. For more information about JSTOR, please contact support@ jstor.org. 


\section{FUNERAL LIGHTS IN ROMAN SEPULCHRAL MONUMENTS.}

(Plates Ix, x).

By G. McN. RUSHFORTH.

Among the fragments of the tomb of the Haterii, discovered in 1848 on the Via Labicana, some three miles from Rome, and now in the Lateran Museum, ${ }^{1}$ are two scenes in low relief illustrating the burial. The first of these (plate Ix) represents a very rare, if not unique, subject-the lying-in-state, as we should call it, in the atrium of the house. ${ }^{2}$ Confining our attention to the details which concern our immediate purpose, we see that the central object is the corpse of a lady extended on a high bed or bier, at the corners of which burn four tall torches standing on the ground, while at the head and foot is a lighted oil lamp on a candelabrum of rather smaller dimensions. Below, at either of the two front corners of the bier, is a small flaming vessel, probably the 'acerra' which Festus says was used for burning incense before the dead. ${ }^{3}$ In the personages who assist at the scene we may recognise the relations, the 'praeficae' or hired mourners, and various attendants, one of whom is apparently laying a wreath on the corpse, which is already crowned, ${ }^{4}$ while another on the right is about to throw more incense on to the ' acerra.' 5

There is one feature in this scene to which no special attention seems to have been paid: I mean the lights round the bier. They are remarkable because they recall the lighted candles similarly set round the coffin, and sometimes round the tomb, in mediaeval and modern Christian usage; and the question arises whether this usage has not a pagan origin, and whether the Lateran relief does not illustrate an ancient practice which was borrowed and continued in Christian funerals. ${ }^{6}$ The use of funeral lights, in

\footnotetext{
${ }^{1}$ Brunn in Annali, xxi (1849), p. 363 ff.; Monumenti, v, 6 ff. cf. Wickhoff-Strong, Roman $A r t$, p. 49, and note quoting Hülsen to the effect that "there can be no doubt that the reliefs belong to the end of the first century' [A.D.].

${ }^{2}$ Lateran, Museo Profano, room x, no. 690. Benndorf-Schoene, Die Antiken Bildwerke des Lateranensischen Museums, p. 22I ; Helbig, Fübrer (3rd ed.), ii, I 192; Annali, l.c. p. 365 .

3 de Signif. Verb. p. 17 (Lindsay)! 'Acerra ara quae ante mortuum poni solebat, in qua odores incendebant.'

${ }^{4} \mathrm{Mau}$ in Pauly-Wissowa, Real-Enc. iii, 348 (Bestattung), points out that the crowning of the dead with wreaths is proved for the imperial age by Tertullian, de Corona, 10: 'mortuorum est ita coronari'; and Minucius Felix, Oct. I2: 'nec
}

mortuos coronamus' (of the Christian usage). Cic. de Leg. ii, 6o, shows that this was an old Roman custom. ${ }^{5}$ In addition to the references given above, see A. Mau, Bestattung, in Pauly-Wissowa, Real-Enc. iii, p. 349 (who describes the torches as torch-like thymiateria); E. Cuq, Funus in Saglio, Dict. ii, p. I 389 , fig. 3360; Baumeister, Denkm. i, fig. 218, and p. 240; Marquardt-Mau-Henry, Vie Privée des Romains, i, p. 406, note 6.

6 The mediaeval usage is thus described by Rock, Cburch of our Fatbers (ed. Hart and Frere), ii, p. 382. When the corpse was brought into church 'at its four corners were put large wax tapers.' (Note 49) 'Such is often the way a funeral is to be found figured in old illuminated manuscripts.' cf. iii, p. 7 I ff. and notes for instances. 
the western mediaeval world at least, is so universal that one would suppose that, if it was derived from a pre-Christian custom, that custom must have been fairly common; otherwise it would never have obtained a footing in the new religion. In the following pages I have brought together such evidence as I have been able to discover illustrating the existence and prevalence of the custom in the Roman world.

At the outset we are met by the difficulty that, in its representation of lights round the bier, the Lateran relief is unique. There are examples of the death-bed scene, showing the family gathered round the couch, and, perhaps, the 'conclamatio.' 1 And the relief of Amiternum, to which attention has lately been called in the pages of this Journal, displays the funeral procession. ${ }^{2}$ But the intermediate stage, the lying-in-state in the case of persons of rank and importance, is represented, so far as I know, only in the Lateran relief. It must be remembered that any scene representing a funeral is rare in ancient art; a rarity which may be contrasted with the hundreds of pictures of mediaeval funerals which we possess, owing to the fact that in illuminated liturgical or devotional manuscripts the Office of the Dead is regularly accompanied by a picture of the funeral service in church, and, sometimes, of the actual interment.

We are not much better off when we turn to literature; but it is possible that a passage in Persius (iii, IOz) may describe a lyingin-state with lights:

\section{Hinc tuba, candelae, tandemque beatulus alto compositus lecto crassisque lutatus amomis in portam rigidas calces extendit: at illum hesterni capite induto subiere Quirites.}

This ought to mean that, when a death takes place, a trumpet is sounded, candles or lamps are lighted, the body is laid out on a high bier in the atrium with its feet towards the door, and is finally carried to its burial by the freedmen who have just been emancipated under the will of the deceased. It is only by a violent disregard of the order of the words that commentators (e.g. Conington) who knew only of torches and trumpets used in the funeral procession, so interpret the 'tuba' and 'candelae' of this passage. On the other hand A. Mau saw that they must refer to ceremonies which immediately followed the death. ${ }^{3}$ The chief difficulty is with the word 'tuba', for two of the reliefs on which Mau and Baumeister" rely for evidence of the custom have been shown to be forgeries. ${ }^{5}$ However, there is a genuine sarcophagus relief at Rome, which

\footnotetext{
1 e.g. British Museum, Catalogue of Reliefs, 2315; Ancient Marbles, v, pl. 3, fig. 5 .

${ }^{2}$ Mrs. Strong in F.R.S. iv (I9I4), p. 153 , and Apotbeosis and After Life, p. 175 and pl. xxiii.
}

\footnotetext{
${ }^{3}$ Pauly-Wissowa, iii, p. 348 .

${ }^{4}$ Denkm. i, p. 309, fig. 325 .

${ }^{5}$ E. Cuq in Saglio, ii, p. 1387 (funus).
} 
shows quite clearly the death-bed scene with a man close by blowing a trumpet ${ }^{1}$; and in the last episode of the Cena Trimalchionis of Petronius (78) the host, in a rehearsal of his own death and funeral, begins by sending for the 'cornicines' :

Cornicines in triclinium iussit adduci, fultusque cervicalibus multis extendit se super torum extremum et 'fingite me' inquit ' mortuum esse. dicite aliquid belli.' Consonuere cornicines funebri strepitu.

We may then, I think, accept the passage of Persius as an account

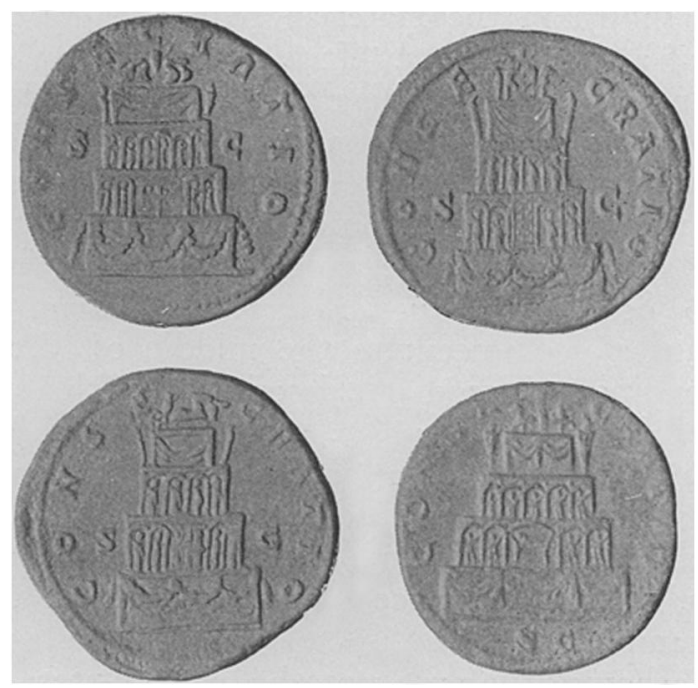

FIG. 37. ROMAN IMPERIAL 'CONSECRATIO' COINS (p. I52).
I. Antoninus Pius.
2. Marcus Aurelius.
3. Faustina Junior.
4. Maesa.

of a lying-in-state, and use the Lateran relief as an illustration of the 'candelae.'

If lights were a regular adjunct at the lying-in-state and funeral of important persons in the imperial age, we should expect to find them prominent at the funerals of emperors. Accounts of some imperial funerals of peculiar splendour have come down to us, ${ }^{2}$ and, in the case of Septimius Severus, Herodian describes the ceremonial and the 'rogus' with much detail. ${ }^{3}$ But nowhere is there any mention of lights. That they were used, however, seems to be proved by a series of coins referring to the 'consecratio' or apotheosis of emperors and empresses of the second and third

\footnotetext{
${ }^{1}$ Saglio, loc. cit. fig. $335^{8}$ (in the Vicolo del Piombo).

2 Dio Cass. lvi, 34, 42 (Augustus); lxxiv, 4 (Pertinax).

3 iv, 2.
} 
centuries. Four typical examples are shown in fig. $37 .{ }^{1} \mathrm{We}$ see the monumental funeral pyre built up in stages decorated with characteristic sarcophagus designs, the topmost being surmounted by the chariot of apotheosis; while at each corner of the highest stage is fixed a lighted torch or candelabrum. It will be noticed that the sarcophagus designs include the familiar ones of festoons of fruit and flowers, the door of Hades flanked by figures in niches or arcading, and the arcaded front with figures in the openings. The topmost stage looks like a draped 'lectus funebris' or bier. The torches at its corners in the case of Antoninus are of the same type as those shown in the Haterian relief : those of Marcus and Faustina are of a simpler form. It is not obvious why they incline outwards. On the coins of Maesa they are replaced by candelabra of more elaborate design, which stand upright. Another peculiarity of Maesa's 'rogus'2 is the representation on the second stage of the corpse of the empress lying on a 'lectus' in the central opening of the arcade, agreeing with the words of Herodian (iv, 2, 8) : ‘́s $\delta \dot{\eta}$

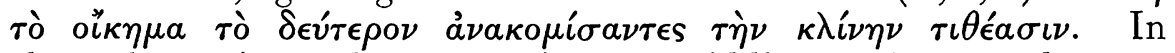
the other coins a door occupies the middle of the second stage, again corresponding to Herodian's description of this story (iv, 2, 7 ):

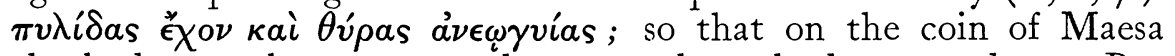
the body may be represented as seen through the open door. But as the door is closed in the other cases, it is more probable that we see only a relief or painting (cf. Herodian, l.c.) of the corpse on its 'lectus,' taking the place of the door which concealed it in the earlier examples.

These coins show us the pyre, not the lying-in-state, but I think we hardly are going beyond the evidence if we regard them as illustrating and confirming the torches round the bier in the Lateran relief. Moreover, we do possess one account of an imperial lying-in-state, that of Constantine the Great. It is an important instance, not only as being a definite piece of evidence for the practice which we are investigating, but also as occurring at a date, and in connection with an emperor, which make it a sort of link of continuity

$1 \mathrm{Mr}$. G. F. Hill (to whom I am indebted for the selection of the coins in fig. 37 , and for the casts taken from specimens in the British Museum) informs me that these imperial pyres with torches first appear on 'consecratio' coins (aurei, denarii, sestertii) of the Antonine period, and that, though the type of the pyre can be traced down to Constantius Chlorus, the coins of Maesa seem to be the latest on which the torches figure. $\mathrm{He}$ gives the following list (made under the present somewhat limited conditions of investigation) of coins on which they occur :

Antoninus Pius.

Denarius. Cohen, ii, p. 228 : I64.

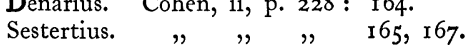

Marcus Aurelius.

Aureus. Coll. Montague, pl. xirI, 40I.

Denarius. Cohen, iii, p. I2 : 97 .

Sestertius. $, ", \quad, 98$.

Faustina Junior.

Denarius. $\quad, \quad$, p. I42:81.

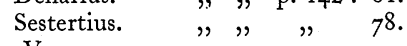

L. Verus.

Denarius. $\quad, \quad, \quad$ p. $377: 5^{8}$.

Sestertius. $\quad, \quad, \quad, \quad 59$.

Pertinax.

Sestertius. $\quad, \quad, \quad$ p. 391 : I2.

Maesa.

Denarius. $\quad$ iv, p. $392: 5$.

Sestertius. " ",$"$ Ib. 6 .

2 Noticed by Eckhel, Doctr. Num. viii, p. 468 . 
between the pagan and the Christian usage. Eusebius in his Life of Constantine tells us that the body, enclosed in a gold coffin, was carried to Constantinople, and there exhibited in one of the principal rooms of the palace on a lofty catafalque surrounded by lights in gold candelabra. ${ }^{1}$ We may regard this as a piece of traditional court ceremonial, the multiplication of the lights being, perhaps, due to the increasing magnificence of the imperial surroundings in the fourth century. ${ }^{2}$

In connexion with this account of Constantine's funeral we may recall the marble candelabra which once formed part of the furniture of the church of Santa Costanza at Rome. It is now recognised that Santa Costanza was an imperial mausoleum of the Constantinian house, ${ }^{\mathbf{3}}$ and it was there, no doubt, that two of Constantine's daughters, Helena and Constantina, were buried ${ }^{4}$ in the magnificent porphyry sarcophagus now in the Vatican. ${ }^{\mathbf{5}}$ It is clear from Marangoni's account ${ }^{6}$ that, until it was moved by Alexander IV in 1256 , this sarcophagus stood in the middle, immediately under the dome: in other words it was the principal object in the building. But it was not the only ancient piece of furniture the church contained. In the seventeenth century the neighbouring basilica of Sant' Agnese had a set of six ancient marble candelabra which are known to have been brought from Santa Costanza, ${ }^{7}$ perhaps in 1467 , when Paul II carried off the sarcophagus. When Ciampini wrote, two had been restored to Santa Costanza, and one had disappeared, as there were only three in Sant' Agnese. ${ }^{8}$ 'These five still exist, one in Sant' Agnese, and the rest in the Vatican Museum. ${ }^{9}$ I suggest that they formed part of the original furniture of the mausoleum, that they had a funerary intention, and that they stood round the sarcophagus like the candelabra round Constantine's coffin. As we shall see presently, the lights of the dead are more or less permanent, either in symbol or in fact; and though they need not be kept burning continually, as is done between the death and the burial, they form part of the furniture of the tomb, to be lighted on anniversaries and other occasions demanded by the cult of the dead. One may compare the mediaeval use of permanent candlesticks round important tombs. ${ }^{10}$ It is to be noticed that in all four candelabra now in the Vatican the

\footnotetext{
1 iv, 66 : (The coffin was set) $\beta a ́ \theta \rho \omega \nu \dot{\epsilon} \phi^{\prime} \dot{v} \psi \eta \lambda \hat{\omega} \nu$

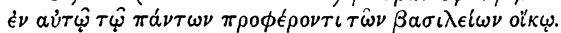

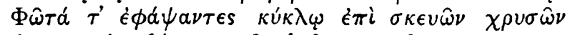

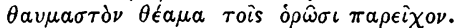

2 The big candlesticks round the coffins of Turkish sultans in their tombs may well be derived from Byzantine imperial usage.

${ }^{3}$ Armellini, Cbiese di Roma (2nd ed.), p. 860 ; Duchesne, Lib. Pont. i, p. 196 ; Rivoira, Lombardic Arcbitecture, i, p. I1, ii, p. 25.

4 Ammianus Marc. xxi, I, 5: 'in suburbano viae Nomentanae.'
}

${ }^{5}$ Helbig, i, 309. The one with the vintage scenes.

${ }^{6}$ Cose gentilesche, p. 299 ; Lanciani, Storia degli Scavi, i, p. 33 .

${ }^{7}$ Martinelli, Roma ex etbnica sacra (Rome, r653), p. 53 .

${ }^{8}$ De sacris aedificiis, p. 134 .

${ }^{9}$ Helbig, i, 341, 342, 353, 354 .

10 e.g. the tomb of Richard Beauchamp, earl of Warwick (d. 1439), in the Beauchamp chapel, Warwick. 
I54 FUNERAL LIGHTS IN ROMAN SEPULCHRAL MONUMENTS.

Eros on one face of the triangular base has been erased, which must mean that one side was more exposed than the others, and being in a church was, at some time, deprived of its pagan imagery. It has occurred to me that two faces would be thus concealed or protected if we were to suppose that the candelabra stood in the

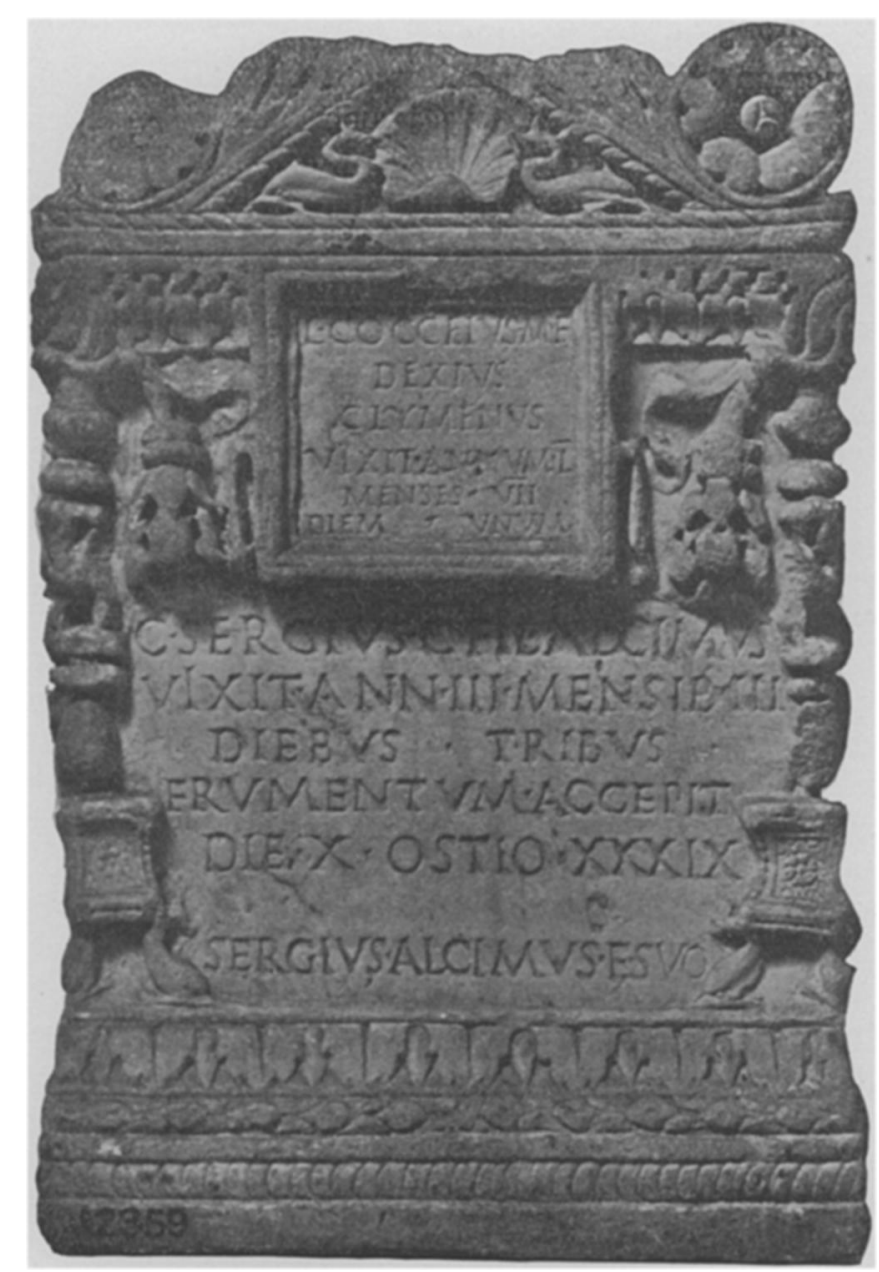

fig. 38. CipPUS in the british MUSEUM (2359) (p. 155).

series of niches which break the inner surface of the wall of the annular aisle in Santa Costanza. There are twelve of these niches, so that, if all held candelabra, six must have been lost or gone astray. It might be worth considering whether some of the very similar candelabra bases scattered in various museums may not 
have come from Santa Costanza. The fact that through wear and tear they had lost their shafts, and were no longer available for use as church candlesticks, might account for their separation from the more perfect specimens of the series when these were removed to Sant' Agnese. Of course the original set in Santa Costanza were not contemporary work like the sarcophagus, but the productions of at least two centuries earlier, and brought together, probably, from different sources. To find a uniform set of twelve, or even of six, would have been difficult or impossible, so that we need not expect them to be exactly alike. In fact the five specimens still at Rome belong to two patterns. ${ }^{1}$

We will now turn to evidence of a different kind. If the literary references to funeral lights are rare, there are a number of monuments which help to illustrate the practice. Familiar objects in museums are the marble chests or cippi for holding the ashes of the dead, mostly dating from the early empire; and it is not uncommon to find the angles of those of the square type carved with candelabra or torches (fig. 38). ${ }^{2}$ Speaking generally, it may be said that everything on a cippus is symbolic, and not merely decorative $^{3}$; and these candelabra or torches represent and, as as it were, make permanent the lights which attend the body both before and after burial. The earliest chest that Altmann can date is the beautiful cippus, in the Louvre, of Amemptus, a freedman of Livia, and therefore belonging, probably, to the reign of Tiberius. ${ }^{4}$ At each of the four corners is a torch, very similar to those which burn round the bier in the relief of the Haterii. As a rule the light-holders at the four corners are not uniform. For instance, I have not come across any example with four candelabra. ${ }^{5}$ When there are candelabra at the front angles there are torches at the back, ${ }^{6}$ and sometimes the back corners are left plain. ${ }^{7}$ In other cases there are torches only at the back angles the front ones being occupied by columns or palms. ${ }^{8}$ I will not attempt to explain these varieties, but call attention to the form which has a pair of torches or candelabra, not at the corners, but

\footnotetext{
1 The two types now in the Vatican are illustrated by Ciampini, t. xxix, flgs. 3 and 4 ; Visconti, Mus. Pio-Cl. vii, pp. 244, 245; Reinach, Rép. de Reliefs, iii, pp. 4I6, 417. Lists of candelabra-bases of similar character are given by Benndorf-Schoene, p. 326 ; Hauser, Neu-Attische Reliefs, p. Iog f. All these triangular bases appear to have rams' heads at the upper angles and sphinxes at the lower, but the reliefs on the faces are either (a) Erotes ending in arabesques and holding fruit or flowers (the five examples in Rome are of this type); or (b) flying Erotes carrying the arms of Ares, illustrated by the British Museum base (Cat. 2509; Marbles, i, pl. 6).

${ }^{2}$ W. Altmann, Die römiscben Grabaltäre der Kaiserzeit, ch. x, where fourteen are described; but the list might be increased.
}

${ }^{3}$ V. Macchioro, Il Simbolismo nelle figurazioni sepolcrali Romane (Memorie della R. Accademia di Archeologia di Napoli, i, 1908), pp. 36, I29.

${ }^{4}$ Altmann, $I I$, and t. $i$ and ii. He is described as ' divae Aug(ustae) 1(iberti).'

5 The descriptions in Michaelis (Anc. Marb.) of cippi at Broadlands (30, p. 225) and Holkham (99, p. 317) suggest four candelabra in either case, but $I$ have ascertained that this is not so.

${ }^{6}$ e.g. Benndorf-Schoene, $189=$ Altmann, 112 ; Florence, Uffizi, $176_{5}=$ Altmann, 116 (who does not mention the torches).

${ }^{7}$ e.g. Michaelis, p. 225 (Broadlands, 30).

${ }^{8}$ Altmann, I28 (Louvre), 172 (Vatican, Amelung, t. 84 , p. $780:$ :686a), 187 (Pisa). 


\section{I56 FUNERAL LIGHTS IN ROMAN SEPULCHRAL MONUMENTS.}

on the face of the cippus, flanking the central object; sometimes the epitaph, ${ }^{1}$ or the door that represents the entrance to the other world, ${ }^{2}$ or the figure of the deceased. ${ }^{3}$ The same effect is produced when the dead person, reclining on a couch-the

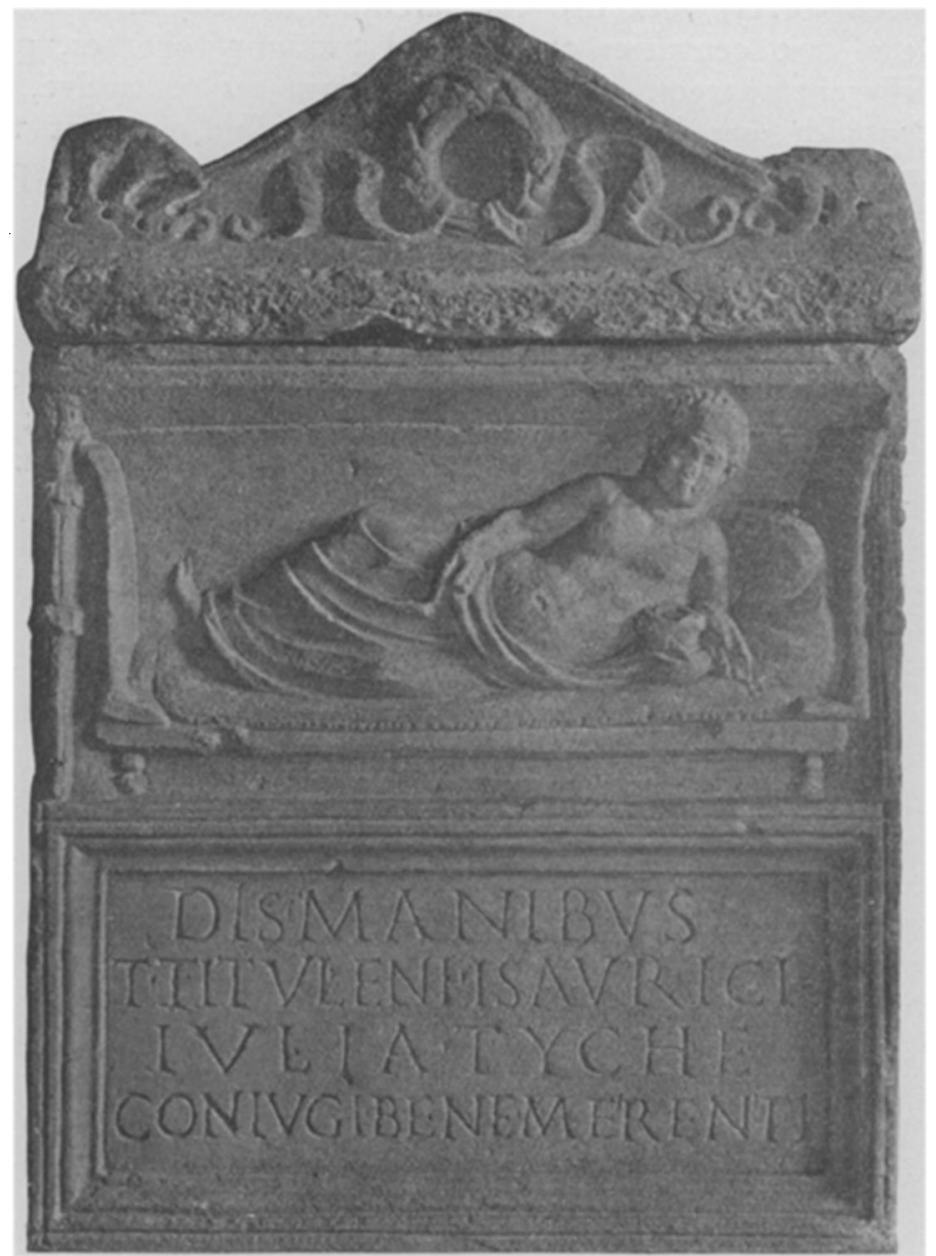

FiG. 39. CipPUS IN The BRItish MUSEUM (2377.)

so-called 'banquet of the dead' scene-taking up the whole breadth of the front, is brought into inmediate relation with the angle torches (fig. 39). ${ }^{4}$

I may note by the way that I have met with only one

1 Brit. Mus. 2379 (Marb. v, pl. I, 4) =Altmann, 106 ; Michaelis, p. $37^{8}$ (Ince-Blundell, 231).

2 Benndorf-Schoene, $260 \mathrm{~b}$.
3 Altmann, 109.

Brit. Mus. 2377 (Marb. v, pl. Ir, 4); Michaelis, p. 406 (Ince-Blundell, $33 \mathrm{I}$ ). 
sarcophagus having candelabra at the angles, ${ }^{1}$ no doubt on the principle stated by Macchioro that the symbol proper is found regularly on the cippus, but only exceptionally on the sarcophagus. ${ }^{2}$

In some of the instances given above we saw that the lights represented on cippi are, as it were, attendant on the dead person. and we may bring this into connexion with what is known about lights as one of the regular forms of the cult of the dead. ${ }^{3}$ When the town of Pisa instituted an annual commemoration of their deceased ' patroni,' the grandsons of Augustus, Lucius (died A.D. 2) and Gaius Caesar (died A.D. 4), it was directed that, after an official sacrifice by the magistrates of an ox and a sheep, 'si qui privatim velint manibus eius inferias mittere, nive quis amplius uno cereo unave face coronave mittat' (together with a sort of imitation of the funeral pyre). ${ }^{4}$ We also find persons leaving directions by their wills for the maintenance of lights at their tombs. Thus a testator directs that 'omnibus $\mathrm{K}$ (alendis) Nonis Idibus suis quibusq(ue) mensibus lucerna lucens sibi ponatur.' ${ }^{5}$ Another asks a community on behalf of a third person deceased 'ut huius manibus lucerna quotidiana ex ratione publika vestra poni (placeat).' 6 Or the request is quite general, as in a metrical epitaph from Salerno :

\section{Quisq(uis) huic tumulo posuit ardente lucernam illius cineres aurea terra tegat. ${ }^{7}$}

In another case the offering is directly connected with the effigy of the deceased. Lucius Cassius Restutus of Auzia in Mauretania Caesariensis directs his heir 'ut statuam meam et uxoris meae terge[at et unguat] et coron[et et cer]eos II accendat.' 8 In all these cases we have the rite of lighting a lamp or candle for the deceased; and it would seem that the candelabra and torches represented on cippi refer to and symbolise or make permanent the lights which attend the dead, continuously, perhaps, till the actual burial, and afterwards at stated intervals or anniversaries. ${ }^{9}$

Though on grounds of symmetry the lights are generally represented on monuments in pairs or fours, the epigraphic and documentary evidence suggests that a single light was the usual offering to the dead. There may be an illustration of this in a

1 Vatican, Gall. Lap. xxix, 126 (Amelung, i, p. 257 , who describes the objects as 'thymiateria'; Reinach, Rep. iii, p. 415).

2 Il Simbolismo, p. 37. Macchioro does not discuss the meaning of light-holders on sepulchral monuments, perhaps because they are not so much symbolical as representative.

3 The following instances are taken from Marquardt and other well-known books of reference. ${ }^{4}$ C.I.L. xi, 20, 1. 23; Dessau, i, 139, 1. 2.4 ;

Wilmanns, 883, i, 1. 27.

${ }^{5}$ C.I.L. vi, 10248

6 C.I.L. ii, 2102.
${ }^{7}$ C.I.L. x, 633; Bücheler, Carm. Epigr. I 308. Mr. G. F. Hill suggests that the object on the reverse of the coins apparently referring to Gaius Caesar (Brit. Mus. Cat. ii, p. 42, 4468) may be a candelabrum in connexion with his death. It has hitherto been described as an incense-altar (Hill, Historical Rcman Coins, 107, p. 165, pl. xv).

${ }^{8}$ C.I.L. viii, $905^{2}$.

9 The subject of lamps and candelabra found in tombs and graves would require a separate investigation. It is touched upon in Marquardt, Vie privée, i, p. $43^{\circ}$. 


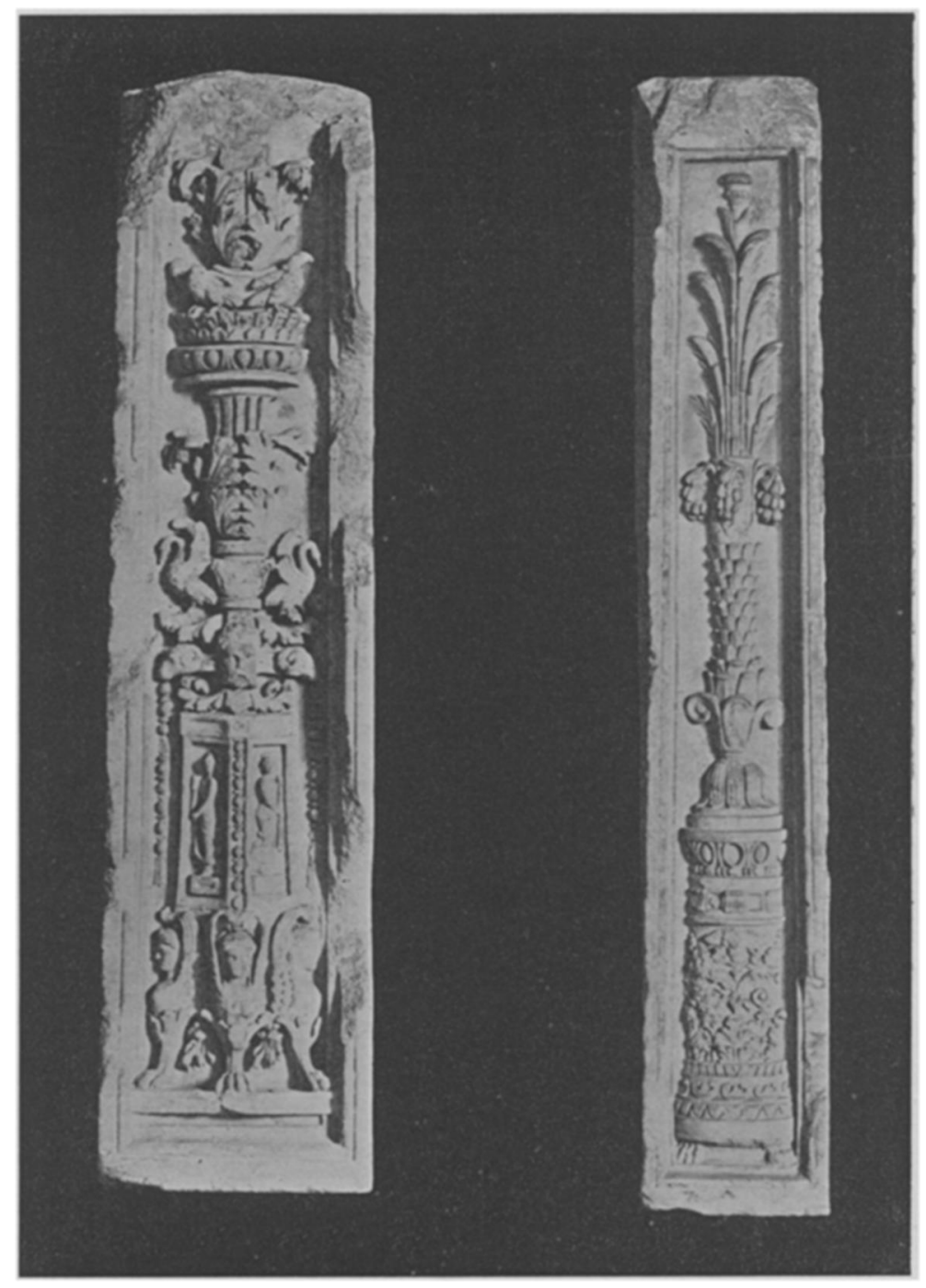

FIG. 40. PILASTERS WITH RELIEFS OF CANDELABRA IN THE ASHMOLEAN MUSEUM, OXFORD (P. 159). 
gravestone, now in the Terme Museum at Rome, which shows a boy, C. Iulius Saecularis, standing in a niche, at one side of which is represented a pine tree, and at the other a candelabrum nearly as tall as himself. A torch is tied to the middle of the shaft. ${ }^{1}$ Moreover, there are plenty of instances of cippi on which a single light-holder is represented in a central position and often made part of a symmetrical design by being set between a pair of griffins. ${ }^{2}$ The design was, of course, of Greek origin, and primarily refers to the symbol of the god of light guarded by the mythical creatures. sacred to him. This would be enough to explain its presence on. sepulchral monuments where the light of the dead is represented. But the fact that such monuments show other emblems of Apollo. (we find the griffins guarding the tripod, ${ }^{3}$ and the laurel bough is often represented on the sides of cippi ${ }^{4}$ ) suggests that he is thought of as in some way connected with the cult of the dead. ${ }^{5}$

The cippi are not the only sepulchral monuments on which candelabra were represented. Many of these belong to freedmen, and probably came from columbaria. But what of the great tombs of noble or wealthy families, such as that of the Haterii ? If our line of thought is correct, these ought to display the symbolic lightholders in even greater prominence. As a matter of fact, they occur on several of the fragments from the tomb of the Haterii. A dedicatory inscription (only the left half is preserved) was flanked, like the epitaph on cippi, by a pair of elaborate candelabra. ${ }^{6}$ A lost relief represented a member of the family as priestess of Dispater, standing between another pair. ${ }^{7}$ And the objects round which the roses climb in the reliefs on the three-sided marble pillar, so well-known from Wickhoff's use of them to illustrate illusionism in Roman art, though sometimes described as vases or balusters, may well be candelabra. ${ }^{8}$ But I would call special attention to the relief in the Lateran forming a pendant to the lying-in-state, and showing a picture of the tomb itself (plate $\mathrm{x}$ ). ${ }^{9}$ At least one, if not two, of the pilasters at the side of the upper story appears to have a relief of a candelabrum. I would compare with this two pilasters in the Ashmolean Museum at Oxford, representing respectively a typical candelabrum, and another in the form of a. palm tree (fig. 40). They came from the neighbourhood of

1 Altmann, 284, fig. 179; Montfaucon, v, pl. 39 ; C.I.L. xiv, 2717. One would think that here, as on the cippi where both torches and candelabra occur combined or separately, some distinction between them must be intended. One might fancy, for instance, that the torches stood for the transitory lights used at the funeral, and the candelabra for the more permanent cult-lights of the tomb. On the other hand, in the Pisan cult of the dead Caesars (see above p. I 57) the cereus and fax are mentioned as alternative offerings.

${ }^{2}$ Altmann, I75, I76; Benndorf-Schoene, 305b, 310; Michaelis, p. 515 (Marbury, 43). Altmann,
165 , fig. 119 , shows the variety of a torch flanked by sphinxes.

${ }^{3}$ Altmann, 46 , fig. 70 .

4 Altmann, 19, etc.

5 Altmann, p. 274.

${ }^{6}$ C.I.L. vi, I9150; Benndorf-Schoene, 355 ; Altmann, p. 27, fig. I8.

${ }^{7}$ Altmann, p. 24 ; C.I.L. vi, 2243. It is known. from a drawing in the Codex Pighianus.

${ }^{8}$ Benndorf-Schoene, 346; Wickhoff, Roman Art, p. 5०, pl. vir and viri; Reinach, Rep. iii, p. 287.

9 Benndorf-Schoene, 344 ; Helbig, ii, I I94; Wickhoff, Roman Art, fig. 20; Reinach, Rép. iii, p. 285 . 
Smyrna, and seem to be work of the first or second century A.D. I suggest that they belonged to some monumental tomb, and, together with a third pilaster decorated with vine foliage, form a parallel to the pilasters of the tomb-temple of the Haterii. ${ }^{1}$ The British Museum, again, has two smaller pilasters (not a pair) decorated with conventional foliage forming a candelabrum, as in the pilaster represented on the tomb of the Haterii, which may have come from a similar source. ${ }^{2}$ With these, perhaps, may be classed a framed panel in the British Museum with the relief of a candelabrum. Its convex surface suggests that it may have formed part of the surface-decoration of a circular tomb like that of Caecilia Metella. ${ }^{3}$ It is true, of course, that lights and candelabra were also used in the worship of the gods ${ }^{4}$; and, for the same reason of magical perpetuation of the light, may be represented on temples as well as on tombs. The candelabra on the surviving external marble decoration of the portico of the Pantheon are an instance. ${ }^{5}$ But, as we shall see, this cult of the gods with lights is practically identical with the cult of the dead by lights, so that the question in all these cases is not so much one of principle as of probability; and the free use of candelabra on the cippi makes it probable that these pilaster and other reliefs come from tombs rather than from temples.

In the Lateran relief last mentioned (plate $\mathrm{x}$ ), above the tombtemple appears a separate scene which, we may suppose, represents the cult of the dead person in the interior of the tomb. The bracket or shelf on which the group stands is supported by eagles, between which are festoons and the sacrificial emblems; all characteristic of sepulchral imagery. Reclining on a couch, just as in the ordinary funeral banquet scenes, lies the lady whom we saw laid in state in the first relief, and whose bust, like that of a deity, adorns the pediment of the temple. In her right hand she holds a bird. Below her is a group of three (presumably her own) children playing; probably the children whose busts are represented on the side of the tomb. Then come the objects connected with the cult of the dead. To the right of the children stands a small flaming altar, on to which an old woman is sprinkling incense, and at the foot of the couch rises a tall flaming candelabrum, which I take for the conventional representation of the usual ' cereus,' just as the altar represents the other part of the offerings to the dead.

On the right, at the other end of the couch, we see the image of a nude woman enshrined in an elaborate architectural setting. I take this for the altar-piece or reredos (so to say) in the end wall

\footnotetext{
${ }^{1}$ Michaelis, Oxford, 224, 225, 226, where 'Syracuse' is an error as Prof. P. Gardner informs me.

${ }^{2} 2606,2607$ : The poppy-heads on 2606 have a definite funerary meaning. Another pair of pilasters $(2666,2667)$ are of similar character.
}

${ }^{3} 2208$; Marbles, ii, pl. II.

${ }^{4}$ Marquardt-Brissaud, Le Culte chez les Romains, i, p. 200 , ii, p. 396.

${ }^{5}$ Visconti, Museo Pio-Clementino, tav. A, iv, 9, and p. 43 . 
of the cella, ${ }^{1}$ where the image of the deity of the temple is displayed; and there can be little doubt that Brunn was right in believing the figure to represent the deceased lady, deified under the form of Venus. He well compares the passage in a poem of Statius describing the burial of Priscilla, wife of Abascantus, in a grand tomb on the Appian way, and the portrait-effigies which present her in the guise of various deities-above all, of Venus :

Mox in varias mutata novaris

effigies; hoc aere Ceres, hoc lucida Gnosis,

illo Maia luto, Venus hoc non improba saxo.

Accipiunt vultus haud indignata decoros numina. ${ }^{2}$

The three heads above the shrine do not concern us now, though I would suggest that they may be the portrait-masks, perhaps in wax, of the three children or of the lady and two of them. But there is another detail which seems to have been overlooked by those who have discussed this relief, namely, the lighted candelabra which flank the image. Lights, as we have seen, were used in the cult of the gods; but I think it is in this case a matter of indifference whether they attend the image as a divine person or as a dead person, because the two things are here identical, as perhaps they were identical in origin. ${ }^{3}$

Having now surveyed, however superficially, the evidence of the classical period, let us consider very briefly the parallel Christian usages. ${ }^{4}$ Here again the evidence is not very abundant. If the practice of attending the dead with lights was universal or even common in Christian circles, it was only occasionally represented on their monuments. But the effigy of a Hateria in apotheosis between a pair of lights, which we have just described, does seem to be nearly related to a number of Christian gravestones and other memorials showing the deceased under the regular type of the soul in prayer-the so-called 'orans' or 'orante'-between a pair of lighted candles. A well-known instance is on the lid of the fifth-century silver box from Numidia, now in the Vatican Christian Museum. ${ }^{5}$ Here we see the person commemorated standing on a mount whence flow the four rivers of Paradise, while the divine hand holds the crown of victory or of eternal life above his head. The sides of the box continue the symbolism of the Christian mosaics, and show clearly that the whole scene takes place in the heavenly country. And this is what gives importance

\footnotetext{
1 Brunn (1. c. p. 402) compares the niche flanked by columns at the end of the cella of the tomb near the Ponte Nomentano.

2 Silvae, v, i, 23r ff. I adopt Prof. Davies's text in Postgate's Corpus. Brunn, 1. c. p. 404.

${ }^{3}$ For effigies of the deceased under the form of a deity see Altmann, p. 282, Macchioro, p. 125.
}

${ }^{4}$ See I.eclercq's article Candélabre in Cabrol, Dictionnaire d'Arcbéologie Cbrétienne, vol. ii, pt. 2, col. I834 ff.

${ }^{5}$ Cabrol, Dict. vol. i, col. 72 r, fig. I48; Muñoz, $L$ 'art byzantin à l'exposition de Grottaferrata, p. 152 ;. Lowrie, Christian art and arcbaeology, fig. $\mathbf{1 6}$. 
to another detail not derived from the mosaics, namely, the pair of tall candlesticks with lighted candles between which the orans stands. ${ }^{1}$ This gives the clue to the other Christian representations of an orans between lighted candles and ' in pace,' as the inscription generally says. It is the soul of the deceased, the glorified spirit, which is thus attended by lights; and here, no doubt, they mean the light and glory of Paradise. Paradise in early Christian art and literature appears as a garden ; and so, on a rather rude gravestone picture from Aquileia, we see three orantes standing in a row (perhaps a father, mother, and son-the four-year-old 'puer Iohannes in pace' of the epitaph) between two flowering plants, and two tripod candlesticks with lighted candles. ${ }^{2}$ They are in the light of the garden of Paradise. But though the lights of the dead were thus given a Christian meaning, I think there can be little doubt that they were a continuation of the traditional pre-Christian usage; and that the 'cerei' offered to the Roman dead, and represented on their monuments, have become the candles which attend the glorified Christian soul. There could be no question of any cult of the dead in early Christianity; but customs are hard to eradicate, and we know how often the Church borrowed ancient forms and gave them new meanings. Perhaps the best proof of the pagan origin of Christian funeral lights is the fact that sometimes they met with opposition, as the prohibition by the Council of Elvira (early fourth century) shows. ${ }^{3}$ This may help to explain why the archaeological evidence is so local. There may have been less opposition, for instance, in Africa, where these representations are fairly common, than there was at Rome where, apparently, only one instance of the orans between candles has come to light. Be that as it may, this Roman example, now exhibited among the Christian inscriptions in the Lateran Museum, showing Bessula ' in pace' standing with her hands outstretched in prayer between two elaborate candlesticks holding lighted candles, $\mathbf{4}$ forms a parallel to the image of the deified Hateria between her burning candelabra. There has been a change in art, in culture, in religious belief; but the fundamental idea of the two representations is the same, and we can hardly doubt that there is continuity between them.

Let us now try to sum up our results. Lights in connexion with the dead are found in many countries and among primitive

\footnotetext{
${ }^{1}$ An almost exact pagan parallel is the cippus of Hateria Superba (Florence, Uffizi. Altmann, rog; Montfaucon, v, pl. 40, 2) showing a girl standing between a pair of torches, as tall as herself, while two Cupids hold a wreath above her head.

${ }^{2}$ Bertoli, Anticbità di Aquileia (Venice, 1739), p. 334, cccclxxxiv; C.I.L. v, 1673. Apparently now in the museum at Aquileia.
}

${ }^{3}$ Mansi, Concilia, ii, col. II, can. 34 : 'cereos per diem placuit in coemeterio non incendi : inquietandi enim spiritus sanctorum non sunt.'

\footnotetext{
${ }^{4}$ Gallery of Inscriptions, xiv, 44 ("ex agro Verano'). Cabrol, Dict. (Chandelier), vol. iii, col. 2 II; De Rossi, Mus. Epigr. t. xv, n. 44; Garrucci, Storia, vi, t. 485 .
} 
peoples. The original idea may have been simply to give the dead one of the things they want-light. Of this primitive use of lights for the dead I can find no trace in early Roman usage. Torches, indeed, by ancient custom, accompanied the body to the place of burial, but this was explained by the fact that originally, owing to religious scruples, funerals took place at night. - It is only in the Augustan age that we begin to find the evidence for that use of lights for the dead which we have been considering. We may divide it into two parts : before burial, and after burial. The former is illustrated by the lying-in-state of the Haterian relief, and one hesitates to exclude all possibility that this is in some way connected with the primitive idea of illuminating for the dead the darkness of death. But it must be remembered that evidence that such usage was primitive is wanting. After burial, on the other hand, we find something rather different-a cult of the dead by means of lights. Perhaps we should distinguish the two things; first, lights used to give light to the dead, a material conception; and, secondly, lights used as a form of the cult of divine beings (including the spirits of the dead), the origin of which is more difficult to explain. ${ }^{1}$ It is found among different peoples and religions, especially in the East, and the Roman use of lights in the cults of the gods and the dead may have been an importation like other religious practices and beliefs. In any case, the offering of lights to the dead seems to have been exactly like the offering of lights to the gods, and I think we may assume that the one practice was an extension of the other. If this be so, it is, perhaps, significant that the evidence for this cult of the dead by lights begins with the Augustan age, just when we find the idea of glorified immortality and apotheosis coming into vogue. ${ }^{2}$ It is because the dead have become merged in the divine, and are even represented in the likeness of particular gods, that they share in the cult of lights and other offerings. When we come to Christian times we still find the use of lights in connexion with the dead, but with this difference : there is no longer any cult of the ordinary dead, and the lights by which they are attended only symbolise the light of Paradise- - the 'lux perpetua' of the Catholic liturgy. The cult use of lights is now reserved for the saints; so that in the fully developed mediaeval practice, which it is difficult to suppose was not continuous with ancient and pre-Christian usage, though the evidence for the continuity is far from complete, we get an interesting parailel to the two usages which we found under the early empire: on the one hand the lights round the bier, perhaps carrying out the primitive idea of lighting up the darkness of death, continued in

\footnotetext{
1 The latest treatment of this subject is in S. Eitrem's Opferritus und Voropfer der Griechen und Römer (Kristiania, I915), esp. pp. I42, I 53 ff.

${ }^{2}$ Macchioro, p. 125. Mrs. Strong, Apotbeosis and After Life, lect. iii.
} 
Christian usage at the lying-in-state, at the funeral service, and sometimes permanently round the tomb; and on the other hand the cult by lights of the glorified dead, represented in the Christian world only by the canonised saints and martyrs. It is difficult to believe that there is not some historical connexion between the two sets of phenomena, and that here, as on other occasions, the Catholic church has not adapted for its own purposes rites and customs which have their origin in pre-Christian ideas and practices. ${ }^{1}$

1 I have to thank Mrs. Strong for much help in writing this paper, and also Messrs. Dalton, Hill, and A. H. Smith of the British Museum, and
Prof. Gardner of Oxford, for information or permissions to reproduce objects in their custody. 


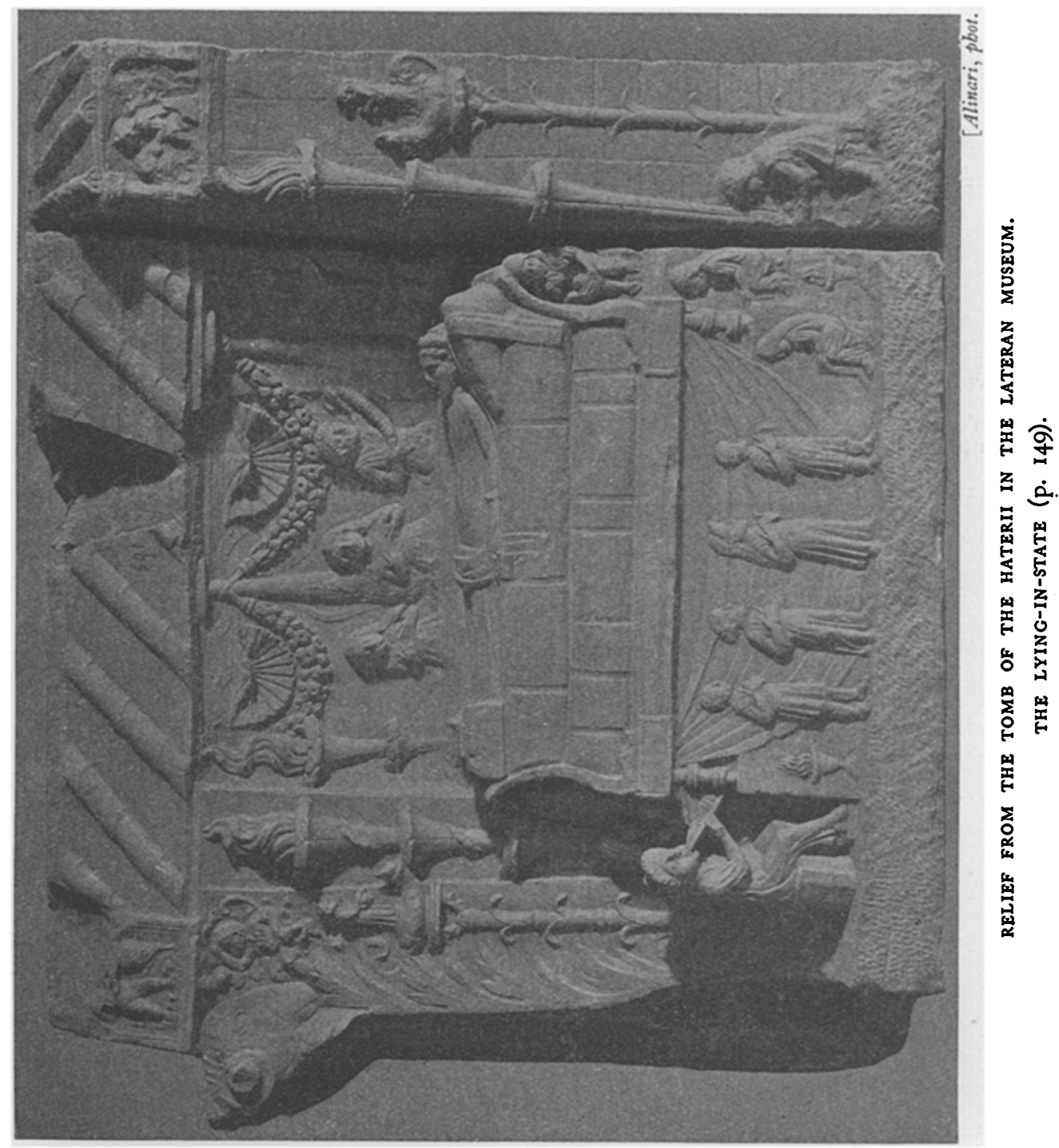




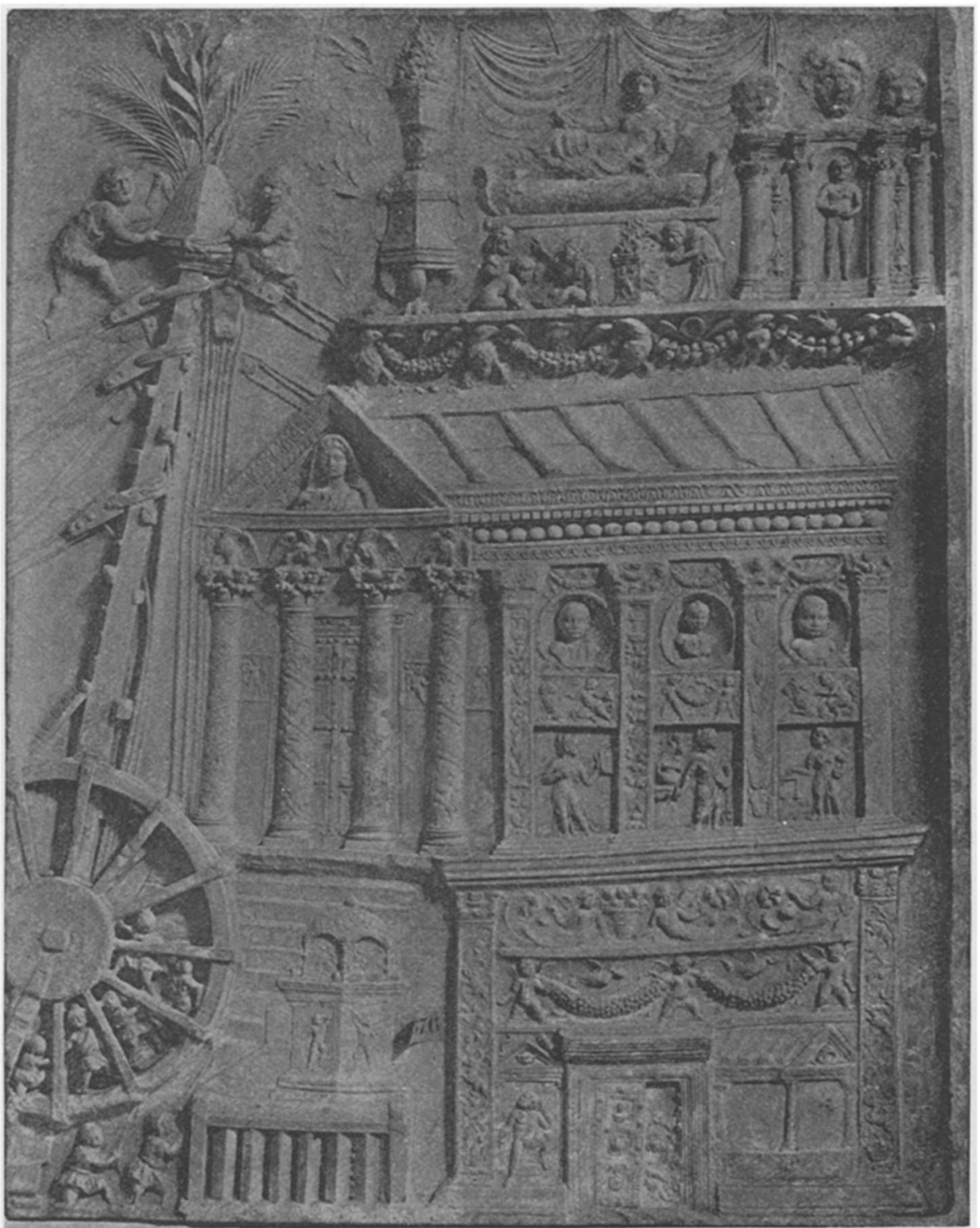

[Alinari, pbot.

RELIEF FROM THE TOMB OF THE HATERII IN THE LATERAN MUSEUM.

THE TOMB AND ITS INTERIOR (p. I 59). 